\title{
SOIL AMENDMENT WITH SEWAGE SLUDGE AND ITS IMPACT ON SOIL MICROFLORA
}

\author{
Rosana Faria Vieira*; Célia Maria Maganhotto de Souza Silva \\ Embrapa Meio Ambiente, Jaguariúna, SP, Brasil
} This paper corresponds to an "extended abstract" selected for oral presentation in the $22^{\text {nd }}$ Brazilian Congress of Microbiology,
held in Florianópolis, SC, Brazil, in November 17-20, 2003

\begin{abstract}
The objective of this work was to verify the effect of frequent sludge soil amendments on the soil's activity and microbial biomass C. Results showed that the use of excessive sludge doses could be detrimental to the soil's microflora.
\end{abstract}

Key words: microorganisms, nitrogen, biosolid.

\section{INTRODUCTION}

The utilization of sewage sludge in agricultural fields is gaining popularity as a means of waste disposal. This organic material can enhance soil productivity as a consequence of its high organic matter and plant nutrient contents. At the same time, sewage sludge could pose a risk to the ecosystem because of the presence of heavy metals and toxic organics (4). The aim of this work was to evaluate the effects of urban sewage sludge application on the soil's activity and microbial biomass $\mathrm{C}$.

\section{MATERIALS AND METHODS}

The experimental site was located in Jaguariúna, State of São Paulo, Brazil on a loamy/clayey-textured Dark Red Dystroferric Oxisol cultivated with maize. The first sludge application was made in April, 1999. The second was made in December, 1999 and the third in October, 2000. The soil's chemical characteristics measured at the beginning of the experiment were: $\mathrm{pH} \mathrm{H}_{2} 05.8, \mathrm{OM} 2.55 \%, \mathrm{P} 3.5 \mathrm{mg} \mathrm{dm}^{3}, \mathrm{~K} 1.51, \mathrm{Ca} 27.5, \mathrm{Mg}$ 8.5, Al 1.0, H 35, CEC $73.5 \mathrm{mmol}_{\mathrm{c}} \mathrm{dm}^{3}$ and V $50.8 \%$. The sludge utilized was an anaerobic sludge from Barueri, State of São Paulo (Table I). The evaluations described in this paper were performed on the first and third cultivations.
The experiment was set up as a completely randomized block design with three replications and the following treatments: control without fertilization or sludge $(\mathrm{C})$, chemical fertilization $(\mathrm{CF})$, sludge dose $1(1 \mathrm{~N})$, sludge dose $2(2 \mathrm{~N})$, sludge dose $3(4 \mathrm{~N})$, and sludge dose $4(8 \mathrm{~N})$. Dose 1 was calculated based on the $\mathrm{N}$ content in the sewage sludge and on the amount of $\mathrm{N}$ recommended for maize fertilization. Doses 2, 3 and 4 were, respectively, two, four and eight times dose 1 . The sludge was always uniformly distributed on the soil surface and rototilled to a 20-cm depth. The first soil evaluation, in April, 1999, was done 14 days after sludge incorporation (DASI), the second 13 days after the first and then at twenty-one-day intervals until 152 DASI. Microbial biomass $\mathrm{C}$ (Cmic), (5) and the metabolic quotient $\left(q \mathrm{CO}_{2}\right)$ were measured during this cultivation. The first evaluation was done 7 days before sludge incorporation, in November, 2000. The second was done six DASI and then at twenty-one-day intervals until 132 DASI. The following parameters were measured: microbial biomass $\mathrm{C}$ and dehydrogenase activity (1). Four samples per plot were taken in each sampling period at a depth between $0-20 \mathrm{~cm}$; samples were then combined to form a single compound sample.

\section{RESULTS AND DISCUSSION}

In April, 1999, the Cmic differences in the control treatment, relative to the other treatments, were dependent upon the

*Corresponding author. Mailing address: Embrapa Meio Ambiente, Caixa Postal 69. 13820-000, Jaguariúna, SP. Tel.: (+5519) $3867-8700$. Fax: (+5519) 3867-8740. Email: rosana@cnpma.embrapa.br 
Table 1. Analysis of sewage sludge added to the soil.

\begin{tabular}{lcrrr}
\hline \multicolumn{1}{c}{ Parameter } & Unit & $\begin{array}{c}\text { First } \\
\text { cultivation }\end{array}$ & $\begin{array}{c}\text { Second } \\
\text { cultivation }\end{array}$ & $\begin{array}{c}\text { Third } \\
\text { cultivation }\end{array}$ \\
\hline pH & & 6.6 & 6.4 & 6.4 \\
Nitrogen Kjedahl & $\mathrm{g} \mathrm{kg}^{-1}$ & 26.0 & 26.4 & 38.5 \\
N-ammoniacal & $\mathrm{mg} \mathrm{kg}^{-1}$ & $1,566.9$ & 156 & $2,401.0$ \\
Phosphorus & $\mathrm{g} \mathrm{kg}^{-1}$ & 15.9 & 31.2 & 26.9 \\
Magnesium & $\mathrm{g} \mathrm{kg}^{-1}$ & 3.0 & 3.7 & 4.5 \\
Calcium & $\mathrm{g} \mathrm{kg}^{-1}$ & 40.3 & 22.8 & 47.8 \\
Copper & $\mathrm{mg} \mathrm{kg}^{-1}$ & 1058 & 1046 & 953 \\
Nickel & $\mathrm{mg} \mathrm{kg}^{-1}$ & 518.4 & 483 & 605.8 \\
Lead & $\mathrm{mg} \mathrm{kg}^{-1}$ & 364.4 & 233 & 348.9 \\
Cadmium & $\mathrm{mg} \mathrm{kg}^{-1}$ & 12.8 & 9.5 & 9.4 \\
Zinc & $\mathrm{mg} \mathrm{kg}^{-1}$ & 2821 & 3335 & 3372 \\
\hline
\end{tabular}

In this same year, the high $q \mathrm{CO}_{2}$ obtained on the treatments with the highest sludge doses suggest a microbial biomass with high energy requirements (Fig. 1). Although a high $q \mathrm{CO}_{2}$ is common in communities at the initial stages of development and in communities with a large ratio of active to dormant biomass (2) it can also mean a metabolic stress (3).

In October 2000, based on the evaluation made 10 days before sludge application to the soil, it was verified that, in spite of the two previous compost applications, there was no Cmic effect between the different treatments. At 6 DASI there was an unexplainable decrease in Cmic for all

season in which the evaluation was performed (Table 1). Except for the evaluation performed $68 \mathrm{DASI}$, the presence of sewage sludge in the soil did not seem to affect $\mathrm{Cmic}$; in this evaluation, plots containing sludge showed a greater amount of biomass, possibly because of the formation of microsites with higher moisture contents formed by the compost; no differences were observed between doses. In the first 27 DASI, the lower Cmic values obtained in the control could be due to the lower degree of initial rooting, because no differences were observed later between treatments. The decrease in Cmic in the last evaluation could also be associated with the low soil moisture content in that season.

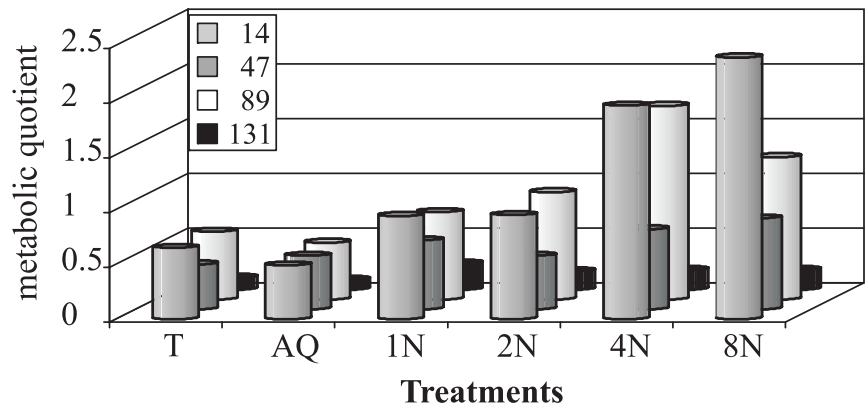

Figure 1. Metabolic quotient ( $\mu \mathrm{g} \mathrm{CO}_{2}-\mathrm{C}$ evolved in 10 days $\mathrm{g}^{-1}$ soil/ $\mu \mathrm{g}$ biomass $\mathrm{C} \mathrm{g}^{-1}$ soil) in a soil amended with different sludge doses.

Table 2. Microbial biomass $\mathrm{C}\left(\mu \mathrm{g} \mathrm{C} \mathrm{g}{ }^{-1}\right.$ soil $)$ in a soil amended with different sludge doses.

\begin{tabular}{|c|c|c|c|c|c|c|c|c|}
\hline \multirow{2}{*}{ Treatments $^{1}$} & \multicolumn{8}{|c|}{ Days after soil sludge incorporation (April, 1999) } \\
\hline & 14 & 27 & 47 & 68 & 89 & 110 & 131 & 152 \\
\hline $\mathrm{C}$ & 61.35 & 121.97 & 204.40 & 123.71 & 210.87 & 191.77 & 217.5 & 148.23 \\
\hline $\mathrm{CF}$ & 136.88 & 160.30 & 208.21 & 122.02 & 210.45 & 211.16 & 248.58 & 131.75 \\
\hline $1 \mathrm{~N}$ & 106.58 & 157.66 & 191.95 & 176.27 & 207.67 & 216.11 & 260.78 & 137.76 \\
\hline $2 \mathrm{~N}$ & 133.87 & 186.11 & 226.47 & 185.12 & 180.37 & 242.86 & 240.09 & 177.37 \\
\hline $4 \mathrm{~N}$ & 93.41 & 148.79 & 229.50 & 163.38 & 202.58 & 217.21 & 244.17 & 148.08 \\
\hline $8 \mathrm{~N}$ & 139.19 & 194.39 & 207.91 & 190.93 & 221.83 & - & 275.48 & 107.33 \\
\hline \multicolumn{9}{|l|}{ DMS } \\
\hline \multirow[t]{2}{*}{ Treatments ${ }^{1}$} & \multicolumn{8}{|c|}{ Days after soil sludge incorporation (October, 2000) } \\
\hline & $\mathrm{BI}^{2}$ & 6 & 27 & 48 & 69 & 90 & 111 & 132 \\
\hline $\mathrm{C}$ & 164.47 & 115.29 & 177.99 & 178.48 & 166.75 & 107.66 & 141.44 & 134.31 \\
\hline $\mathrm{CF}$ & 186.75 & 92.97 & 201.92 & 172.01 & 227.16 & 128.12 & 115.90 & 101.67 \\
\hline $1 \mathrm{~N}$ & 181.37 & 86.16 & 225.37 & 204.33 & 178.99 & 96.14 & 120.03 & 119.76 \\
\hline $2 \mathrm{~N}$ & 202.74 & 91.04 & 236.60 & 254.27 & 210.17 & 138.69 & 207.12 & 143.32 \\
\hline $4 \mathrm{~N}$ & 192.54 & 59.34 & 243.58 & 182.75 & 230.44 & 157.41 & 173.24 & 152.11 \\
\hline $8 \mathrm{~N}$ & 171.54 & 72.19 & 259.55 & 231.57 & 287.02 & 153.14 & 200.58 & 163.07 \\
\hline DMS & & & & & & & & \\
\hline
\end{tabular}

${ }^{1}$ T,control; CF, chemical fertilization; $1 \mathrm{~N}$, sludge dose $1 ; 2 \mathrm{~N}$, sludge dose $2 ; 4 \mathrm{~N}$, sludge dose $3 ; 8 \mathrm{~N}$, sludge dose $4 ;{ }^{2} \mathrm{BI}$, measurement made 7 days before sludge incorporation. 
treatments. In this cultivation season, contrary to what had occurred in 1999, from 27 to 111 DASI there was a trend toward obtaining a smaller Cmic value in the control treatment and higher Cmic values in the two highest sludge doses. Considering, however, the magnitude of the difference in terms of $\mathrm{C}$ organic addition to the soil, in the two highest sludge doses relative to the control treatment, we can conclude that the addition of excessive sludge doses to the soil could be somehow detrimental to the soil's microflora. This hypothesis is backed up by soil dehydrogenase activity data, in which a tendency to obtaining smaller values at the higher sludge doses was verified (Table 3).

Table 3. Dehydrogenase activity (TPF per dry weight; $\mu \mathrm{g} \mathrm{g}^{-1}$ ) in a soil amended with different sludge doses.

\begin{tabular}{ccrrrrrr}
\hline \multirow{2}{*}{ Treatments $^{1}$} & \multicolumn{7}{c}{ Days after soil sludge incorporation } \\
& 6 & \multicolumn{1}{c}{27} & \multicolumn{1}{c}{48} & \multicolumn{1}{c}{69} & \multicolumn{1}{c}{90} & \multicolumn{1}{c}{111} & 132 \\
\hline $\mathrm{C}$ & 2.14 & 3.84 & 5.53 & 9.19 & 9.24 & 9.63 & 11.65 \\
$\mathrm{CF}$ & 1.66 & 2.04 & 4.32 & 11.57 & 11.98 & 12.62 & 8.07 \\
$1 \mathrm{~N}$ & 3.15 & 4.89 & 4.60 & 13.41 & 13.07 & 9.97 & 11.93 \\
$2 \mathrm{~N}$ & 3.70 & 4.88 & 5.40 & 14.73 & 14.21 & 12.74 & 11.82 \\
$4 \mathrm{~N}$ & 3.30 & 2.49 & 3.99 & 10.81 & 12.07 & 7.88 & 10.60 \\
$8 \mathrm{~N}$ & 2.43 & 3.41 & 3.51 & 9.64 & 5.94 & 8.43 & 8.25 \\
DMS & & & & & & & \\
\hline
\end{tabular}

${ }^{1}$ For abbreviations see Table 2.

\section{RESUMO}

\section{Adubação do solo com lodo de esgoto e seu impacto na microflora do solo}

O objetivo deste trabalho foi verificar o efeito de freqüentes aplicações de lodo ao solo na atividade e no C da biomassa microbiana. Os resultados demonstraram que a utilização de doses excessivas de lodo pode prejudicar a microflora do solo.

Palavras-chave: microrganismos, nitrogênio, biossólido.

\section{REFERENCES}

1. Alef, K. Dehydrogenase activity. In: Alef, K.; Nannipieri, P. (eds.) Methods in applied soil microbiology and biochemistry. Academic Press, London, 1995, p. 228-231.

2. Anderson, T.H. Physiological analysis of microbial communities in soil: applications and limitations. In: Ritz, K.; Dighton J.; Giller, K.E. (eds.) Beyond the biomass. John Willey and Sons, New York, 1994, p. 67-76.

3. Anderson, T.H.; Domsch, K.H. The metabolic quotient for $\mathrm{CO}_{2}$ $\left(q \mathrm{CO}_{2}\right)$ as a specific activity parameter to assess the effects of environmental conditions, such as $\mathrm{pH}$, on the microbial biomass of forest soils. Soil Biol. Biochem., 25:393-395, 1993.

4. Banerjee, M.R.; Burton, D.L.; Depoe, S. Impact of sewage sludge application on soil biological characteristics. Agric. Ecosys. Environ., 66:241-249, 1997.

5. Vance, E.D.; Brookes, P.C.; Jenkinson, D.S. An extraction method for measuring soil microbial biomass C. Soil Biol. Biochem., 19:703$707,1987$. 